\title{
New Glands Found at The Omasal End in The Goat
}

\author{
By
}

\author{
Ken-ichiroh MUTOH and Hidekazu WAKURI \\ Department of Veterinary Anatomy, Kitasato University School of \\ Veterinary Medicine and Animal Sciences, \\ Towada-shi, Aomori 034, Japan
}

-Received for Publication, 24 June, 1987-

Key Words: goat, omasum, myoepithelial cell, seromucous gland.

\begin{abstract}
Summary: New glands were observed at the omasal end in 34 goats examined by binocular stereoscopic, light and scanning electron microscopy. They were situated in the submucosa and were classified as compound tubulo-alveolar glands, which consisted of mucous, serous and myoepithelial cells. The myoepithelial cells were found to be of the stellate type by scanning electron microscopy. Morphologically, the glands were considerably similar to the esophageal gland as regards their situation in the mucous membrane and the types of cells forming them.
\end{abstract}

The forestomach (rumen, reticulum and omasum) of domestic ruminants is lined with stratified squamous epithelium. Some evidence has indicated that glands are present in the groove of the reticulum in the sheep and on the base of the omasum in the goat (Zimmerman \& Sal, 1894; Bensley, 1902; Krölling \& Grau, 1960; Habel, 1975; Sato, 1969; Wakuri, 1980). These glands, however, have not been discussed in many papers or textbooks. When the organogenesis of the forestomach is examined, the existence of these glands should be included.

The present paper describes the morphology of the glands present on the base of the omasum of the goat, as revealed by light and scanning electron microscopy.

\section{Materials and Methods}

A total of 34 goats of various ages (Tables 1 and 2) were sacrificed under barbital anesthesia to obtain materials for study. The omasum and part of the abomasum were quickly removed from them and opened along the curvature after having been fixed in $10 \%$ formalin. The omasum was collected from 22 goats (Table 1) to observe the distribution of glands. It was washed with tap water and immersed in a 1:200 aqueous dilution of Delafield hematoxylin solution or in a 3\% acetic acid aqueous solution of $0.1 \%$ alcian blue for $3 \mathrm{hr}$. After rinsing with water, the organ was examined under a binocular stereoscopic microscope to locate the stained excretory openings.

For light microscopic studies, the base of the omasum was dissected out quickly from 12 goats (Table 2) and cut dorsoventrally into pieces about $5 \mathrm{~mm}$ thick. These pieces were fixed in $10 \%$ formalin, embedded in paraffin, and out serially into sections 5 or $10 \mu \mathrm{m}$ thick. Some of these sections were stained with hematoxylin and eosin (H-E), periodic acid-Schiff (PAS), alcian blue (pH 2.5) or phosphotungstic acid hematoxylin 
Table 1. Specimens and location of glands as observed by binocular stereoscopic microscopy
Case Sex Age
No.
Location
of glands
Case Sex Age
No.
Location
$1 \star \sigma 3$ months

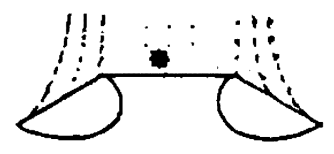
12 శ 1 year
2 \& 5 months

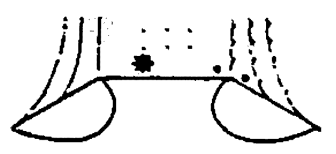
$13 \star \quad$ 우 2 years

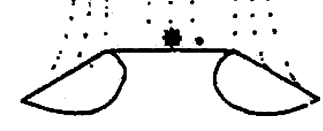
3 ๙ 5 months

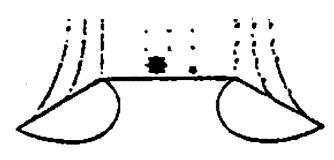
$14 \quad 8^{7} 2$ years

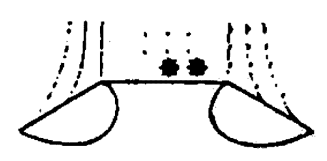
48 months

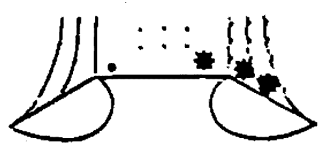
15
우 2 years

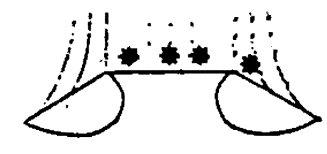
$5 \star \quad \sigma \quad 9$ wonths
6 우 9 months

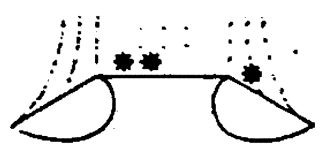
$16 \star \quad$ 우 3 years
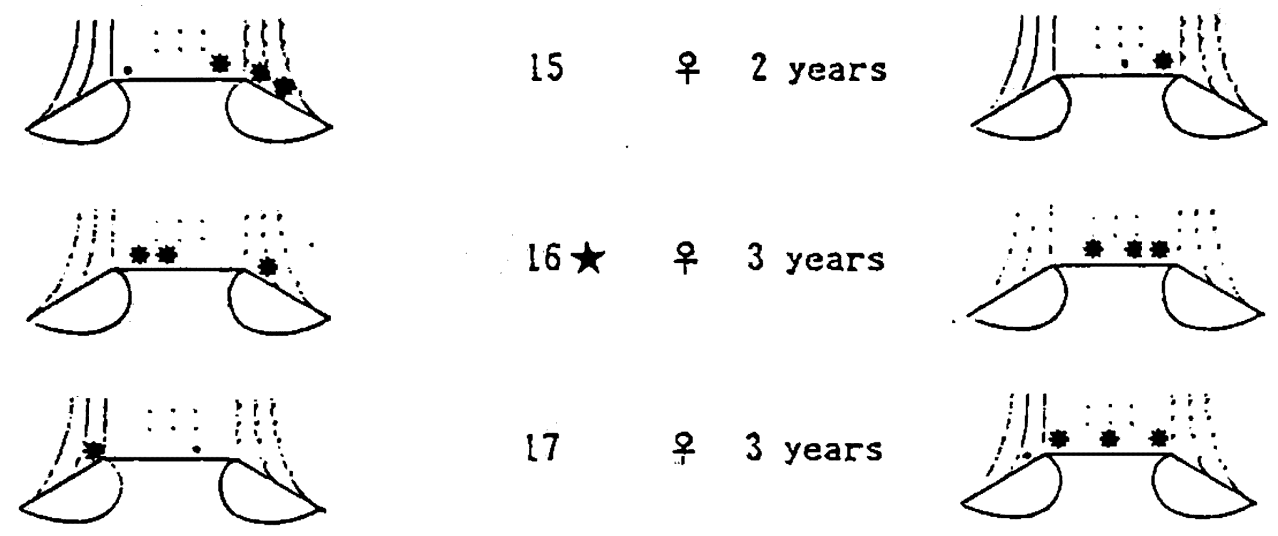
17 \& 3 years

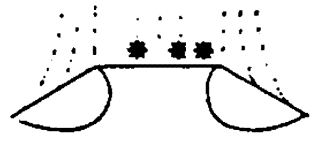
69 우 9 months

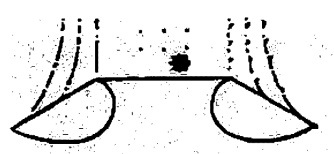
18 i 3 years

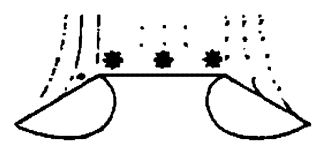
7 \% 9 months

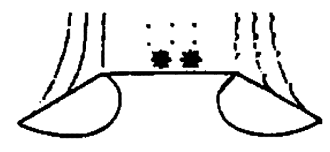
19 ㅇ 3 years
19 ㅇ 3 years

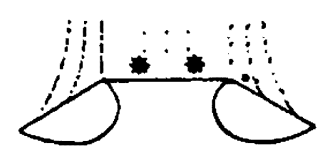
$8 \star \quad$ ㅇ 1 year

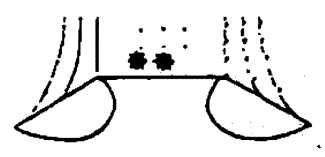
9 우 1 year

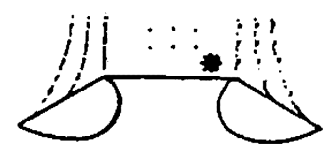
20
우 3 years

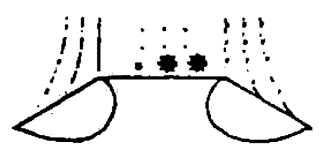
10 우 1 year

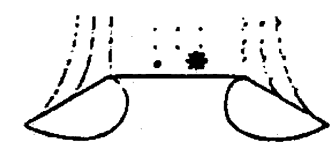
$21 \star$ 우 4 years

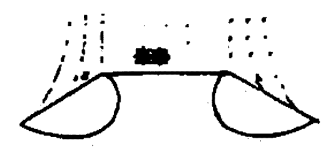
11 오 1 year

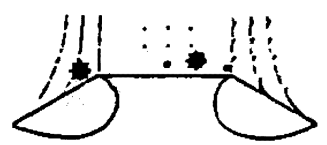
22
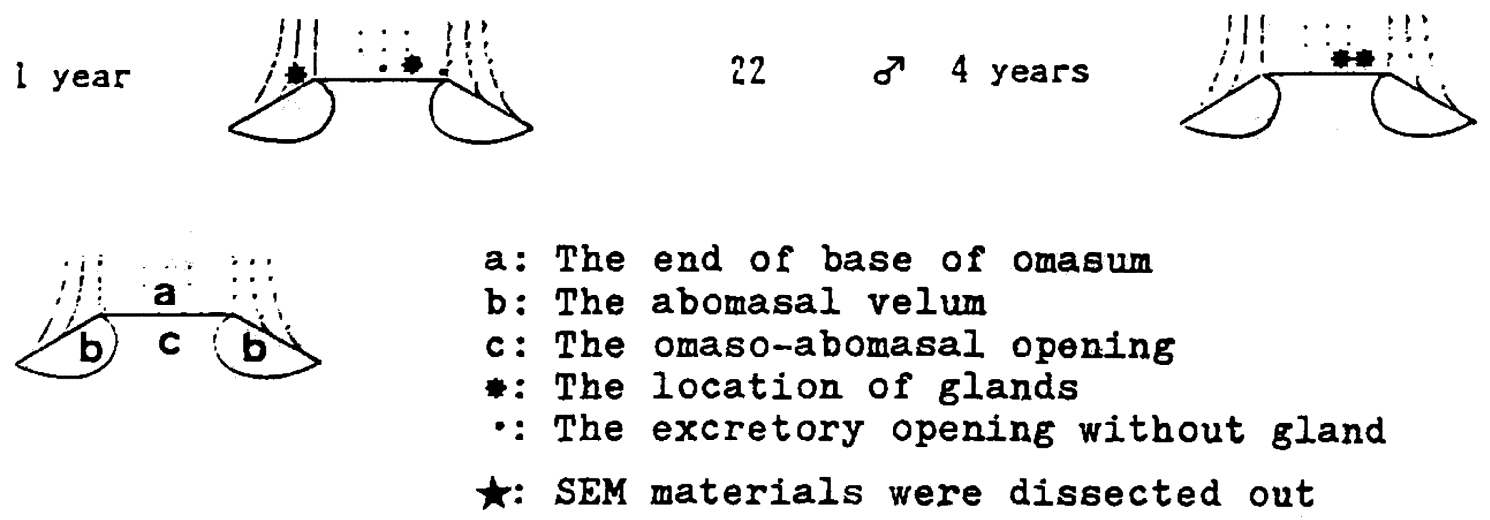
Table 2. Specimens for light microscopic study

$\begin{array}{ccl}\text { Case No. } & \text { Sex } & \text { Age } \\ 23 & \wp & 7 \text { months } \\ 24 & \wp & 9 \text { months } \\ 25 & \delta & 1 \text { year } \\ 26 & \wp & 2 \text { years } \\ 27 & \delta & 2 \text { years } \\ 28 & \wp & 2 \text { years } \\ 29 & \delta & 3 \text { years } \\ 30 & \delta & 3 \text { years } \\ 31 & \wp & 3 \text { years } \\ 32 & \wp & 4 \text { years } \\ 33 & \delta & 4 \text { years } \\ 34 & \wp & 4 \text { years }\end{array}$

(PTAH). Others were refixed in Carnoy's solution after deresin and stained with amide black 10B for myoepithelial cells (Puchtler et al., 1974).

For scanning electron microscopy (SEM), small pieces were dissected out from the glandular region of the omasal end under a binocular stereoscopic microscope (Table 1). They were treated by the HCl-collagenasa method (Evan et' al., 1976) and dehydrated by the critical point method. After being coated with platinum, they were examined under a Hitachi S-450 scanning electron microscope.

\section{Results}

Glands were observed on the base of the omasum in all the goats investigated in the present study. They were ready for examination under the binocular stereoscopic microscope, since their excretory openings were clearly stained. These openings consisted of depressions formed at the center of hillocklike projections and were stained with diluted hematoxylin or alcian blue. Clearer staining was obtained by the latter than by the former method in the present study (Fig. 1).
The glands were situated in the connective tissue of the omasal base near the omaso-abomasal opening. They were small in size $(1-3 \mathrm{~mm})$, oval or round in shape, translucent and presented a multi-alveolar appearance (Fig. 2). They could be distinguished from the spherical cells of the adipose tissue which appeared to be lustrous and uniform, and from the bundles of stick-like smooth muscle fibers. Most of the excretory openings were clearly related to the glands, but a few of them could not be found to be connected with any gland (Table 1). The glands were scattered around the omaso-abomasal opening. They were situated in the deep layer of the stratified squamous epithelium on the abomasal velum (Table 1).

Light microscopy revealed that these glands were compound tubulo-alveolar glands with a wide lumen situated in the submucosa and consisting of mucous, serous and mixed acini. The mixed acini had demilunes. The mucous acini were composed of wide columnar cells which were PASpositive and lightly stained with H-E and PTAH. In these cells, the nucleus was flattened and pushed towards the base by a mucous mass. In the serous acini, the cells were cuboid or pyramidal in shape. They contained PAS-positive granules, which were eosinophilic when stained with H-E, and bluish when stained with PTAH. Their nuclei were round or oval and situated in the basal region or at the center of the cells (Figs. 3-6).

The excretory ducts of the glands passed through the papillae of the lamina propria and opened on the surface of the stratified squamous epithelium. They communicated with wide intercalated ducts situated in the center of the glands. The intercalated duct often branched. The cells of the excretory duct were arranged in three or four layers in the lamina propria and in two or four layers in the submucosa. The cells of the layer 
facing the lumen were cuboidal and those of the peripheral layer resembled the spindleshaped cells of the stratified squamous epithelium. The epithelium of the intercalated duct was composed of light cuboidal cells (Figs. 3-5).

Myoepithelial cells were observed on the base of the epithelium of the intercalated duct and in the acinus when stained with PTAH and amide black 10B. They were slender and spindle-shaped, lying on the basal surface of the epithelial cells. By H-E staining, only their nuclei could be discerned (Figs. 5 and 6). On SEM observation, the myoepithelial cells revealed a stellate cell body with processes radiating towards the basal surface of the gland from the central perinuclear region. These processes formed a continuous network with an end-to-end relationship (Fig. 7).

\section{Discussion}

Although Krölling \& Grau (1960) reported that mucous and mixed glands were often present on the base of the omasum in $45 \%$ of the goats studied by them, these glands were observed in all of the goats examined in the present investigation. In these goats, the glands were situated in the submucosa at the omasal end and differed from the cardiac esophageal gland of man and the cardiac gland located in the lamina propria of mammals (Bensley, 1902; Bloom \& Fawcett, 1968).

In cattle, sheep and goats, esophageal glands are found only at the pharyngeal end of the esophagus. In camels, however, they are distributed throughout the whole length of the esophagus (Jamder \& Ema, 1982). Zimmerman \& Sal (1894) noticed compound tubulo-alveolar glands in the esophageal groove of sheep, and reported that these glands were considerably similar to esophageal glands. The glands observed in the present study were compound tubulo- alveolar ones and consisted of mucous, serous and myoepithelial cells. It is known that myoepithelial cells are present in the mammary, sweat and digestive glands and the prostate (Bloom \& Fawcett, 1968; Stinson \& Calhoun, 1976; Nagato, 1978; Abe, 1979; Caruolo, 1980; Wakuri, 1980; Shimada et al., 1981). In this study, tissue blocks were fixed in 10\% formalin and treated by the HCl-collagenase method. Specimens were prepared from them and observed by SEM, revealing the present of stellate myoepithelial cells on the basal surface of some glands. Many methods have been employed to remove the peripheral tissue from these glands (Nagato, 1978; Abe, 1979; Caruolo, 1980; Shimada et al., 1981).

The esophageal gland of cattle is also a compound tubulo-alveolar one and consists of mucous, serous and myoepithelial cells (Wakuri \& Kano, 1963; Wakuri \& Mutch, 1972). In the esophageal gland of goats, the branched intercalated duct and tubuloalveolar part have a wide lumen (Wakuri, 1980).

The gland observed in the present study is considered to be not an abnormal structure but a gland proper to the organ. It closely resembles the esophageal gland in terms of its morphological characteristics.

Pernkopf (1931), Lambert (1948) and Warner (1958) indicated that the ruminant stomach, like the simple stomach, developed from a simple spindle-shaped primordium. They emphasized that there was no esophageal contribution to the formation of any parts of the forestomach, in spite of the presence of esophageal sacculation (Sisson \& Grossman, 1953; Tamate, 1957; Romer \& Parsons, 1977; Frandson, 1981). Their views were in agreement with those of many previous workers. It was presumed that the forestomach might have no relation to the esophagus (Kawata, 1948; Wardrop, 1961; Habel, 1964; Sato, 1967; McGeady \& Sack, 
1967; Nickel et al., 1973; Kato, 1975; Kano et al., 1981; Fath El-Bab et al., 1985). On the other hand, several workers have reported the presence of glands, which resembled esophageal glands, in the forestomach of sheep and goats (Zimmerman \& Sal, 1894; Krölling \& Grau, 1960; Wakuri, 1980). It is suggested that the area containing such glands might be related to the esophagus in the development of the forestomach.

\section{Acknowledgments}

The authors wish to thank Dr. S. Sakasegawa for his help in preparing this manuscript, and also acknowledge the technical assistance of all staff members of the Department of Veterinary Anatomy, Kitasato University School of Veterinary Medicine and Animal Sciences.

This investigation was supported in part by a Kitasato University School of Veterinary Medicine and Animal Sciences research grant (No. 6001).

\section{References}

1) Abe, J.: Scanning electron microscopic observations of the mammary gland myoepithelial cells of the rat under normal and experimental conditions. Kurume Med. J. 26: 303-310, 1979.

2) Bensley, R.R.: The cardiac glands of mammals. Am. J. Anat., 2: 105-156, 1902.

3) Bloom, W., and Fawcell, D.W.: A Textbook of Histology, 9th ed., p.510-528, W.B. Saunders Co., Philadelphia, 1968.

4) Caruolo, E.V.: Scanning electron microscope visualization of the mammary gland secretory unit and of myoepithelial cells. J. Dairy Sci., 63: 1987-1998, 1980.

5) Eguchi, Y.: Shinpan, The KachikuHasseigaku, p.118-120, Bun-eido Co., Tokyo, 1985 (in Japanese).

6) Evan, A.P., Dail, W.G., Dammrose, D., and Palmer, C.: Scanning electron microscopy of cell surface following removal of extracellular material. Anat. Rec., 185: 433-446, 1976.
7) Fath El-Bab, M.R., Schwartz, R., and Ali, A.M.A.: Micromorphological studies on the stomach of sheep during prenatal life. $\mathrm{Zbl}$ Vet.-Med. C. Anat. Histol. Embryol., 12: 139-153, 1983.

8) Frandson, R.D.: Anatomy and Physiology of Farm Animals, 3rd ed., p.304-331, Lea \& Febiger, Philadelphia, 1981.

9) Habel, R.E.: Guide to the Dissection of Domestic Ruminants, p.36-49, Published by the author, Ithaca, N.Y., 1964.

10) Habel, R.E.: Ruminant digestive system. In Sisson and Grossman's The Anatomy of the Domestic Animals (Getty, R., 5th ed.), p.881-903, W.B. Saunders Co., Philadelphia, 1975.

11) Jamder, M.N., and Ema, A.N.: The submucosal glands and the orientation of the musculature in the esophagus of the camel. J. Anat., 135: 165-171, 1982.

12) Kano, Y., Fukaya, K., Asari, M., and Eguchi, Y.: Studies of the development of the fetal and neonatal bovine stomach. $\mathrm{Zbl}$. Vet.-Med. C. Anat. Histol., Embryol., 10: 264-274, 1981.

13) Kato, Y.: The Kachiku-Hikaku-Hasseigaku, p. 89-90, Yokendo Co., Tokyo, 1976 (in Japanese).

14) Kawata, S.: The Kachiku-no-Hassei, p.148-155, Sangyo-Tosho K.K., 1948 (in Japanese).

15) Krölling, O., und Grau, H. Lehrbuch der Histologie und vergleichenden mikroskopischen Anatomie der Haustire, 10. Auf., p.221-278, Paul Parey, Berlin, 1960.

16) Lambert, P.S.: The development of the stomach in the ruminant. Brit. Vet. J., 102: 302-310, 1948.

17) McGeady, T.A., and Sack, W.O.: The development of the bovine stomach. Am. J. Anat., 121: 121-130, 1967.

18) Nagato, T.: Scanning electron microscopical image of mycepithelial cells. J. Electron Microsac., 27: 235-236, 1978.

19) Nickel, R., Schummer, A., and Seiferle, E.: The alimentary canal of the ruminants. In The Vescera of the Domestic Mammals (Sack, W.O., translation and revision), p.147-168, Paul Parey, Berlin-Hamburg, 1973.

20) Pernkopf, E.: Die Entwicklung des Verderdarmed, insbesondere des Magens der Wiederkäuer. (Eine Vergleichendembryologische Studie). Zschr. Anat,, 94: 490-622, 1931.

21) Puchtler, H., Waldrop, F.S., Carter, M.G., and 
Valentine, L.S.: Investigation of staining polarization and fluorescence microscopic properties of myoepithelial cells. Histochemistry, 40: 241-289, 1974.

22) Romer, A.S., and Parsons, T.S.: The Vertebrate Body, 5th ed., p.339-359, W.B. Saunders Co., Philadelphia, 1977.

23) Sato, Y.: The Kachiku-no-Hassei KaiboYosetsu, p.246-250, Gakuso-sha Co., Tokyo, 1967 (in Japanese).

24) Shimada, T., Nakamura, M., and Inoue, Y.: Removal of extracellular materials by HCITween treatment. Arch. Histol. Jap., 44: 189-192, 1981.

25) Sisson, S., and Grossman, J.D.: The Anatomy of Domestic Animals, 4th ed., p.449-484, W.B. Saunders Co., Philadelphia, 1953.

26) Stinson, A.W., and Calhoun, M.J.: Digestive system. In Textbook of Veterinary Histology, 2nd ed. (Dellman, H.D., and Brown, E.M., ed.), p.207-264, Lea \& Febiger, Philadelphia, 1976.

27) Tamate, H.: The anatomical studies of the stomach of the goat. II. The postnatal changes in the capacities and the relative sizes of the four divisions of the stomach. Tohoku J. Agr. Res., 8: 65-77, 1957.
28) Wakuri, H., and Kano, Y.: Histologische Untersuchungen über der Oesophagusdrüse des Rindes. Bull. Azabu Vet. Coll., 2: 1-11, 1963 (in Japanese with German summary).

29) Wakuri, H., and Mutoh, K.: The fine structure of the cattle esophageal gland with special reference to the myoepithelial cells. Kitasato Arch. Exp. Med., 45: 45-50, 1972.

30) Wakuri, H.: The Organo-Histology of the Domestic Animals. Lecture Outline and Laboratory Guide, 2nd ed., p.31-81, and 226-229, Gakusosha Co., Tokyo, 1980 (in Japanese).

31) Wardrop, I.D.: Some preliminary observations on the histological development of the forestomachs of the lamb. 1. Histological changes due to age in the period from 46 days of fetal life to 77 days of natal life. J. Agric. Sci., 57: 335-341, 1961.

32) Warner, E.D.: The organogenesis and early histogenesis of the bovine stomach. Am. J. Anat., 102: 33-63, 1958.

33) Zimmerman, A., and Sal, J.: Beitrag zur Histologie des Pansens. Deut. Ztschr. f. Thiermed., Leipzig, 20: 283-289, 1894. 


\section{PLATES}




\section{Explanation of Figures}

\section{Plate I}

Fig. 1. Omasal end entirely stained with alcian blue in $3 \%$ acetic acid solution. The abomasal mucous membrane and excretory opening were stained bluish (arrow). $\times 38$.

Fig. 2. Glands at the omasal end (arrow). Peripheral tissue was removed by being picked up with tweezers under a binocular stereoscopic microscope. $\times 38$.

Fig. 3. Light micrograph of a sagittal section through the omaso-abomasal orifice. Glands (arrows) are observed in the submucosa. An excretory duct is indicated with an arrowhead. H-E. X26.

Fig. 4. Glandular terminal in the submucosa at the omasal end. An intercalated duct is located at the center of the tubulo-alveolar gland with a wide lumen. H-E. X130. 

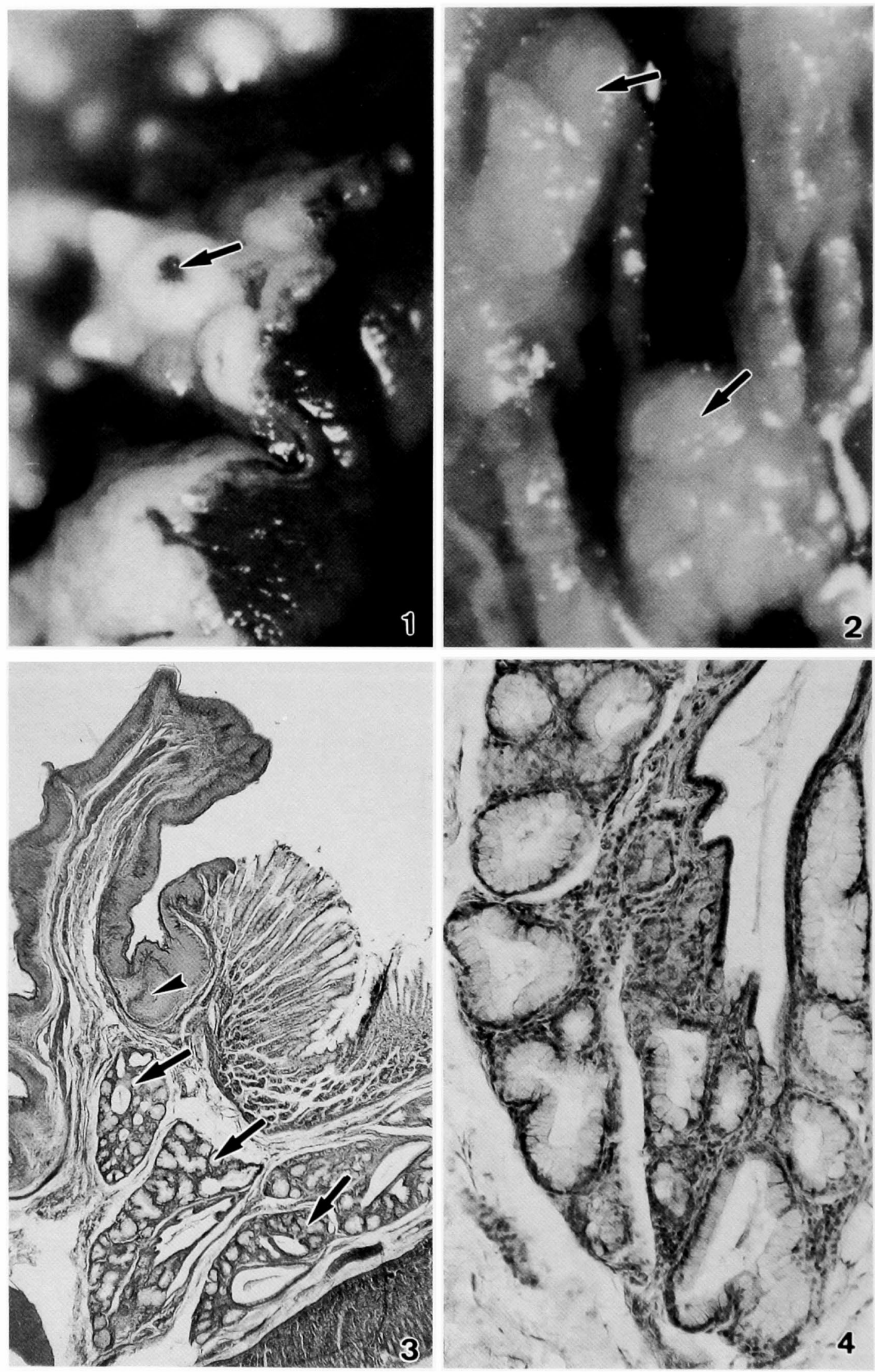


\section{Plate II}

Fig. 5. Mucous and seromucous terminals. Mucous cells are light and wide columnar in shape. Serous cells contain bluish granules (arrowheads). Myoepithelial cells (arrows) are also present. PTAH. X260.

Fig. 6. Mucous and seromucous terminals. Wide columnar mucous cells and cuboidal or pyramidal serous cells are surrounded by slender spindle-shaped myoepithelial cells (arrows). Amide black 10B.X520.

Fig. 7. Scanning electron micrograph of the glandular terminal revealed by removal of extracellular materials. The processes of myoepithelial cells are observed on the surface of the glandular terminal. $\times 780$. 
Plate II
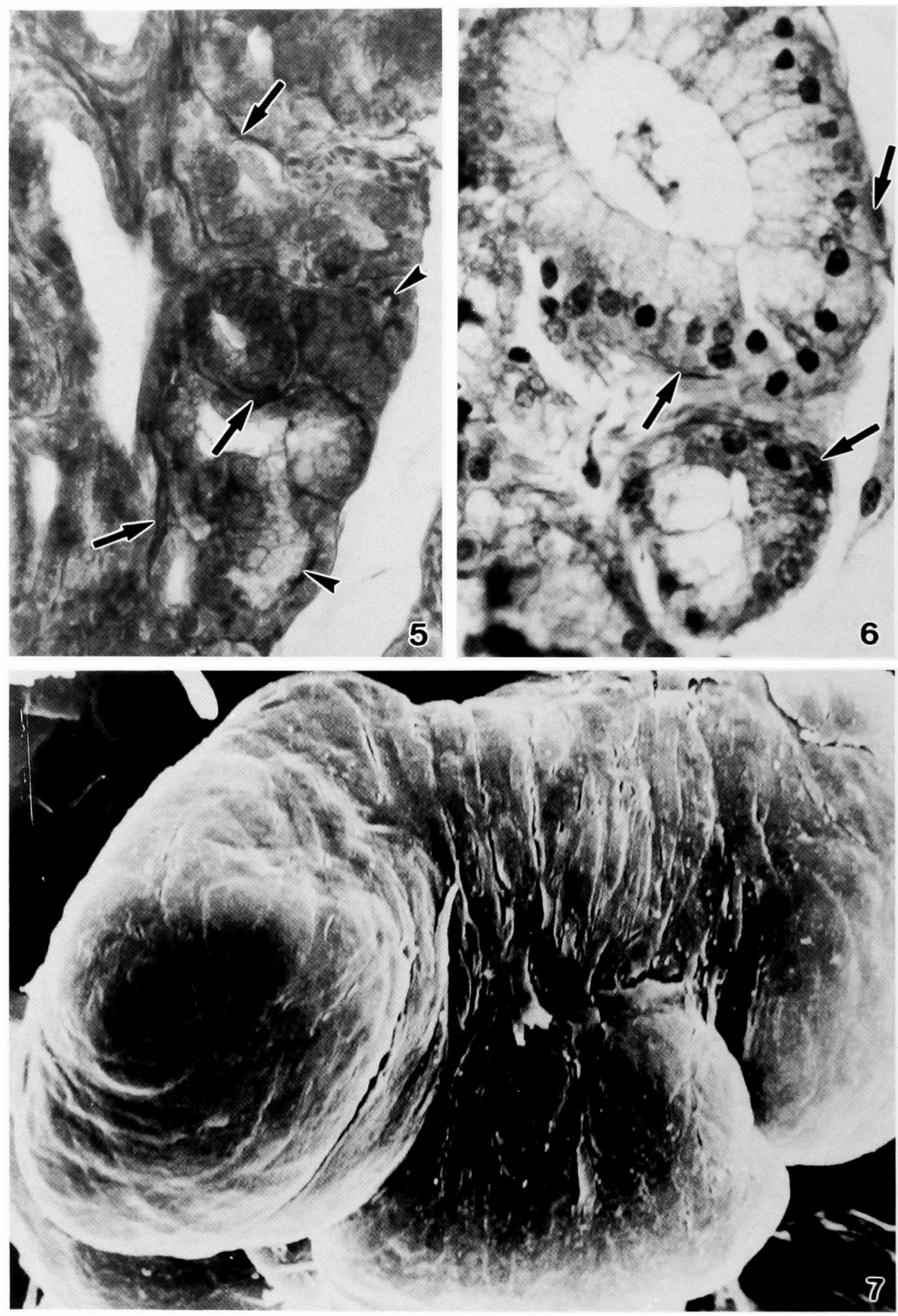